\title{
Developing a Literature-Based Instructional Material for Essay Writing Course
}

\author{
Lestari Setyowati ${ }^{1}$, Sony Sukmawan ${ }^{2}$, dan Ana Ahsana El-Sulukkiyah' \\ ${ }^{1}$ Universitas PGRI Wiranegara, JI. Ki Hajar Dewantara 27-29 Pasuruan, Indonesia \\ ${ }^{2}$ Universitas Brawijaya, Jl. Veteran, Malang, Indonesia \\ e-mail: *lestari.setyowati@yahoo.co.id; sony sukmawan@ub.ac.id;
}

aahsana3@gmail.com

\begin{abstract}
The inclusion of literature for language teaching is not something new. Nowadays, the use of literature is becoming quite common for teaching language skills. The purpose of this study is to develop an instructional material by using literature-based instruction for essay writing course in University of PGRI Wiranegara, Pasuruan. The research used Gall, Borg, \& Gall research and development procedure with some adaptations. The instruments used in the study were questionaires, interview, and tests. The instructional material was tried out and tested to students who joined essay writing class in the academic year 2018-2019. The students' essays were analyzed by using Jacobs ESL Composition profile covering five elements, namely content, organization, vocabulary, language and mechanics. The result of the study shows that the instructional material was proven to be adequately successful to be used for essay wrting course. The use of literature for teaching writing gives benefits for the students, not only in terms of their writing skills, but also in terms of sharpening their critical thinking ability.
\end{abstract}

Keywords: essay, instructional material, literature-based instruction, writing

\section{Introduction}

In the past, literature and language teaching is typically seen as two separate dimensions. But nowadays, there is a growing interest to use literature for language classroom. Moreover the use of literature for language teaching has been widely acknowledged, especially in the area of teaching receptive skills, like reading and listening both in first language and second/foreign language context. So far, there is no clear definition of what it meant by literature-based instruction. Yet, the term of literaturebased instruction can be defined as a technique for teaching language skills (reading, listening, speaking and writing) and language areas (for example grammar, pronunciation, vocabulary) through the use of literature (Hismanoglu, 2005).

The use of literature for classroom teaching has gained its popularity since in the 90 's in which at that time, there was a growing interest to use children literature for teaching reading (Lehman, Freeman, \& Allen, 1994). At that time, the use of literature for reading program's main intention was to increase the students' cognitive reading skill, reading achievement and critical thinking skills (Block, 2005). As the use of literature has gained its popularity in language classroom, its use is no longer confined to reading program only, but cover wider language skills area, like listening, speaking and writing. Hismanoglu (2005) states literature can be used both as a subject matter and a model for teaching writing. The students can write their analysis and interpretation from a selected work which train their original thinking and critical thinking ability. In 
addition, Lazar (2010) states that there are several approaches if literature should be used in the language classroom. They are 1) the language-based approach which its main focus is the study of grammar, vocabulary, and discourse used in the text. 2) literature as content approach which focuses on course content, such as reading and translation, 3) literature for personal enrichment approach which focus on own personal experiences, emotions, and feelings. The purpose of this approach is to enable the students being involved personally and intellectually when they are learning English.

Literature, as stated by Gibson (2007) has close relationship with reality as literature gives better understanding toward life and the world in general. If literature can act as a tool to understand the meaning of life (Setyowati, 2017), then its use for language teaching is very recommended. However, the use of literature for teaching writing skill in the university level of Indonesian context is quite uncommon even though some still can be found in the trace of previous studies. Setyowati \& Sukmawan (2018) investigate the students' opinion on the use of essay to analyze fictions for prose subject. The result of the study shows that the integration between teaching writing and prose give more benefits for the students' language skills as well as their analytical and critical thinking skills.

In the context of teaching writing in university level, it is important for the students to be able to express their ideas in written form while at the same time critically responding and taking part in the solution for global problems. Based on the preliminary research, in the world of the teaching of foreign language writing, more specifically in Universitas PGRI Wiranegara Pasuruan, the materials used for writing course are mostly written and published in the first language context in which many of the topics offered were not enggaging for the students. The reading pasages used in the textbooks, which are used to prepare the students' background knowledge and to stimulate their ideas, are not interesting. Many of them are written in first language context and are not familiar to the students. To write an essay well, the topic should be close to the students' personal life so that they can express their ideas and opinion in written context without many difficulties.

Literature offers a wide variety of genre (short stories, flash diction, narrative poems, poems, plays, etc) that can be used for learning to write for different types of texts (narrative, expository, argumentative, descriptive, persuasive). For example, the students can write an opinion essay responding to the flash fiction while at the same time they are learning how to make thesis statement, giving details and examples, and giving the conclusion (Setyowati, 2016). The students can also write an analysis about the short story they read focusing on the intrinsic elements of the text while at the same time they are learning how to open the essay, writing thesis statement, giving details and examples, and writing proper conclusion (Setyowati \& Sukmawan, 2018). The use of literature for teaching writing benefits the students from many aspects. Since the essay writing course in Universitas PGRI Wiranegara Pasuruan needs better instructional material, this present study is intended to describe how to develop literary-based instructional material for essay writing which is practical and interesting to improve the students' writing skill.

\section{Method}

The study used Gall, Borg, \& Gall (1996) research and development procedure. Gall et al. (1996) proposes ten steps for research and development procedure in education. However, because of the time limit, the present study simplifies the steps into eight, namely preresearch, planning, developing, expert judgment, revising, try out, field testing, and final revision. The expert judgment procedure was put integrated into the developing phase and revising phase. In the pre-research phase, the infromation gathering was done, and need analysis study was also conducted. The main intention 
was to collect the information in relation to the students' needs and problems, as well as the previous studies in related area. The instrument used for the need analysis was library research, questionaire, and interview. The interview was given to the writing lecturers and the head of English education study program of Universitas PGRI Wiranegara Pasuruan, and the questionnaire was given to the students. The next step was planning. In the planning stage, the based-competence of essay writing was identified, as well as approach used for designing instruction. After an extensive review of literature, it was decided to use literature as personal growth or enrichment approach (Lazar, 2010). This approach offers students with analysis both the new words and linguistic elements, but also responding to the literary texts by giving their own personal/real-life experience (Khatib, Rezaei, \& Derakhshan, 2011).

The next step was developing the initial material. The material was designed based on the course syllabus, and the availability of supporting literature. The design was continued to the expert validation in which the evaluator gave suggestions in relation to the format, structures, and wording. The validators were two lecturers from English Education study program from the faculty of Cultural Studies of Brawijaya University. The Revision took place after the validating stage. The next phase was try out. The estimation of the practicality of the materials was done based on the following criteria. First, it was easy and efficient to use, it did not cause confusion in the instructions, and it supported the teaching learning process. The first try out was given to a small scale of students. The result of the trial test would determine the revision whether it was major or minor. The next stage was the field testing. The field testing was given to the students who took essay writing course in the academic year 2018-2019. The effectiveness of theinitial material was seen from the score of the writing test. The students' composition was evaluated by using Jacobs et al ESL writing scoring rubric published in 1981. The researchers decided to use this profile because this profile has been tested and used by many researchers in second language $(\mathrm{SL})$ and foreign language $(\mathrm{FL})$ writing context both in original form or in its adaptation form (Janssen, Meier, \& Trace, 2015). There were two raters involved during the scoring process. The raters were writing lecturers who have been teaching writing courses in the institutions for four years. The information of effectiveness and practicality of the material was taken also from the students' feedback by using semi structured questionnaire. And the last stage was final revision.

\section{Findings}

\section{Need Analysis}

The result of need analysis shows that essay writing course needs teaching materials which are appropriate with the syllabus of English education study program. Based on the result of interview with the writing lecturers and the head of English study Program, it was found out that the English education study program in Universitas PGRI Wiranegara Pasuruan usually uses Oshima and Hogue's book entitled Writing Academic English for essay writing class. The book was considered too thick and not practical because it did not quite match with the syllabus. There were some chapters in the book which could not be finished in one semester. Furthermore, the topic used in the book were considered boring and did not really discussed real life experiences in Indonesian context which connect to the students' life. The result of the questionaire which gives information about the students' perception of writing course and whether they need a handout for the course can be seen in table 1.

Table 1. Results of Need analysis

\begin{tabular}{clll}
\hline & Students' perception of writing & Yes (\%) & No (\%) \\
\hline 1. & Is writing difficult? & $39 \%$ & $61 \%$ \\
\hline
\end{tabular}




\begin{tabular}{lll}
\hline 2. Do we need a handout for writing course? & $93 \%$ & $7 \%$ \\
\hline 3. What is the most difficult chracteristics of & & \\
writing? & $11 \%$ & $89 \%$ \\
a. Idea & $0 \%$ & $100 \%$ \\
b. Organization & $89 \%$ & $11 \%$ \\
c. Grammar & $0 \%$ & $100 \%$ \\
d. vocabulary &
\end{tabular}

Table 1 shows that the majority of the students felt that writing was not difficult $(61 \%)$, while the rest of them felt differently. When they were asked whether they needed a handout for writing course, almost all of them (93\%) said that they needed one. The data also shows that based on the students' opinion, grammar was the most difficult aspect in writing (89\%).

Table 2. The type of handout that the students' need

\begin{tabular}{rll}
\hline \multicolumn{2}{l}{ The handout should provide } & $\mathrm{N}$ \\
\hline 1. & grammar reviews related to the materials & 12 \\
\hline 2. & contains individual and group tasks/activities & 5 \\
\hline 3. & some lists of vocabulary in each unit & 4 \\
\hline 4. & brief explanation related to the tasks and activities & 4 \\
\hline 5. & meaningful activities and attractive design & 3 \\
\hline & Total & 28 \\
\hline
\end{tabular}

Eventhough most of the students gave positive reponse toward the current material, some of them gave feedbacks in relation to the future writing handout. Many of them felt that they needed a writing handout which provided grammar reviews related to the writing materials. This finding matches with the result of need analysis in which they thought that grammar was the most difficult aspect in writing. Therefore, it was concluded that for future essay writing course, a practical, easy to use, and interesting instructional material is needed.

\section{Planning}

Since idea becomes one of the difficult elements in writing, the writing materials were designed based on topics which were close to the students' life. It was a challenge to create an interesting instructional material for essay writing course in which the topics talked about real life experiences while at the same time matched with the syllabus. To have a valid construct, the essay writing course syllabus of English education study program was studied.

Table 3. Essay Writing syllabus

\begin{tabular}{ll}
\hline Course description & $\begin{array}{l}\text { Develop the students' ability to write various types of } \\
\text { English essays: examples, details, comparison and } \\
\text { contrast, cause and effect relations, classification, } \\
\text { problem-solving, process analysis for expository and } \\
\text { argumentative types of essays. }\end{array}$ \\
\hline Base-Competence & $\begin{array}{l}\text { 1. } \begin{array}{l}\text { able to read critically and effectively English texts } \\
\text { both fictions and non fictions to gather } \\
\text { information }\end{array} \\
\text { able to express ideas in written form by using } \\
\text { appropriate and acceptable English }\end{array}$ \\
$\begin{array}{l}\text { Skill-Competence } \\
\text { in Society }\end{array}$ & $\begin{array}{l}\text { Able to think critically and creatively to help solve } \\
\text { problems in social life }\end{array}$ \\
\hline
\end{tabular}

The syllabus states that the students should be able to make different type of essay with the focus on the expository and argumentative type of essay. Literary-based 
instruction was selected based on the following considerations. Firstly, literature is often seen as the depiction of the reality (Gibson, 2007). Literary works offer better understanding of the world and the life itself even though almost all the intrinsic elements found in the literary work (poems, plays, novels and short stories) are imaginary. And secondly, literary works have varied genre which offer rich selection of teaching materials. In the defining stage, literature as personal growth or enrichment approach as proposed by Lazar (2010) was selected.

\section{Developing}

The initial material materials were designed based on the students' need and appropriated with the syllabus. The initial essay writing materials discuss about the difference between paragraph and essay focusing on paragraph and short essay structure, topic sentence, unity and coherence, short essay organization, types of essay, opinion essay, expository essay, argumentative essay, how to open and close the essay, refutation, and how to cite and write references. The result of the design was validated by two lecturers, majoring in reading and writing, from English Education Department of Faculty of Cultural Studies, Universitas Brawijaya. The result of the first validation showed that the initial material lacked of practice in certain units. The units that need more attentions were those that discussed differences between paragraph and essay and essay types. The validators suggested the practice should be added with creating students' own topic sentence in the beginning, while in each unit, the practice should be added with critical thinking questions before jumping into the topic. The validators also suggested to use short stories which are relevant to the topic discussion. To fulfill this, short stories written by famous authors, either classic or contemporer were chosen based on the following considerations. The short stories should be interesting, short in terms of length, appropriate in terms language, appropriate in terms of level of difficulty, and relevant to topic being discussed. Thus, the short stories chosen are The Giving Three by Shell Silverstein under the theme 'environmnetal protection', HC Andersen's short story The little match seller for 'poverty theme'., Shon Mehta"s A Girl Who Asked Why for gender equality theme, and Anand Vishnu Prakash's In a Land not so Far Away for Under-age marriage theme. The validators agree that the short stories were considered apprpriate to be use for writing essay as the topic was relevant to the up to date issue. The validators suggested that before the students gave respond and opinion about the narrative, there should be comprehension questions prior the writing task. The phrases to express opinion should also be given, as well as the clauses that might be useful for the students to express their opinion. Another suggestion given by the validators was the writing instruction should be clear for the students.

\section{Revision}

Based on the expert judgements and suggestions, the initial material was revised. Some exercises before the actual writing phase were added. The exercises covers the use of phrases used to express opinion, such as in my opinion, in my point of view, first of all, secondly, finally, the reason for..., the first reason is, the second reason is. There was also language focus part which specifically discuss the clause which was considered useful to express opinion, such as the adjective clause. Another important revision was the comprehension questions after the students read the fictions. The comprehension questions were intended to provide the students' background knowledge and to connect the passage with their personal life. The comprehension questions activities were designed to be completed in group work.

\section{Try out}

The revision of the initial material was tried-out to the small scale students who took academic writing course. They were asked to do the exercises in the handout. The 
result of the try out shows that there are some problems in the handout in terms of objectives and acitivities. In each chapter, no specific goals were given, so that it might not give focus for the students about their learning. Secondly, some sample texts should be given to the students.

Table 4. Summary of mini try out

\begin{tabular}{|c|c|c|}
\hline & Items in Try Out highlight & Revision \\
\hline 1. & No learning objectives & $\begin{array}{l}\text { Given learning objectives in each unit } \\
\text { (the rhetorical focus and language focus) }\end{array}$ \\
\hline \multirow[t]{6}{*}{2.} & \multirow{3}{*}{$\begin{array}{l}\text { Needs clearer differences between } \\
\text { paragraph and essay } \\
\text { Need specific instruction } \\
\text { Need more practice in controlling idea } \\
\text { and topic sentence } \\
\text { Lack of language review } \\
\text { Impractical exercises about tonic }\end{array}$} & $\begin{array}{l}\text { Given sample of short essay and parts of } \\
\text { essay } \\
\text { Given questions for dicussion about the } \\
\text { sample esay }\end{array}$ \\
\hline & & Given clearer instruction by paraphrasing \\
\hline & & Given more practice i \\
\hline & $\begin{array}{l}\text { Impractical exercises about topic } \\
\text { sentence creation }\end{array}$ & $\begin{array}{l}\text { Given more language focus review and } \\
\text { practice }\end{array}$ \\
\hline & & $\begin{array}{l}\text { Given more practice how to make topic } \\
\text { sentence through pair work from given } \\
\text { topics }\end{array}$ \\
\hline & Items in Try Out highlight & Revision \\
\hline 3. & $\begin{array}{l}\text { More clarification of different type of } \\
\text { essay }\end{array}$ & $\begin{array}{l}\text { Given more, yet practical, explanation, } \\
\text { about types of essay } \\
\text { Given shorter sample essay with practice }\end{array}$ \\
\hline & Too long sample essay & \\
\hline 4. & $\begin{array}{l}\text { Lack of language review } \\
\text { Need more comprehension questions for } \\
\text { the fiction }\end{array}$ & $\begin{array}{l}\text { Given some language review: adjective } \\
\text { clause and some practices } \\
\text { Given more comprehension questions: } \\
\text { reading beyond the line questions to } \\
\text { stimulate emotions and personal opinion. }\end{array}$ \\
\hline
\end{tabular}

Based on the data from the mini try out, the initial material was revised and made ready for the field testisting. Before it was presented for wider audience, the initial material was shown to the validators for further suggestions.

\section{Field Testing}

The initial material was tested to the students who joined the essay writing course in the academic year 2018-2019 in Universitas PGRI Wiranegara Pasuruan. Each unit covered two meetings and it took two months for the field testing to complete. Before the students wrote the essay, they were asked to read the narrative by heart, and find the difficult words. They were also asked to discuss the comprehension question about the story. The discussion took 30' from class hour, then the students were given 60 ' to write an essay responding to the short story.

Some problems arouse from the writing instruction. During the writing task, some students asked questions about the relationship between the instructions whether they should make one essay or three essays. The students also got confused to tailor questions 1,2, and 3 in the writing up section because it was the first time for them to write an essay by responding to a literary work. However, the result of the tryout showed otherwise. Most of the students gave positive responses toward the use of the handout.

Table 5. Results of try-out questionaire

\begin{tabular}{|c|c|c|c|}
\hline $\begin{array}{c}\text { Strongly } \\
\text { Disagree } \\
\text { (SD) \% }\end{array}$ & $\begin{array}{l}\text { Disagree } \\
\text { (D) } \%\end{array}$ & $\begin{array}{l}\text { Agree } \\
\%\end{array}$ & $\begin{array}{l}\text { Strongly } \\
\text { Agree } \\
\text { (SA) \% }\end{array}$ \\
\hline
\end{tabular}




\begin{tabular}{|c|c|c|c|c|}
\hline $\begin{array}{l}\text { Content: } \\
\text { Correspond to teaching aims and } \\
\text { students' needs }\end{array}$ & $0 \%$ & $5 \%$ & $82 \%$ & $13 \%$ \\
\hline Suitability to teaching and learning & $55 \%$ & $9 \%$ & $68 \%$ & $18 \%$ \\
\hline \multicolumn{5}{|l|}{ Language } \\
\hline $\begin{array}{l}\text { is suitable (clearly understandable) to the } \\
\text { students' linguistic level }\end{array}$ & $0 \%$ & $0 \%$ & $64 \%$ & $36 \%$ \\
\hline $\begin{array}{l}\text { uses the correct and meaningful } \\
\text { grammatical structure }\end{array}$ & $0 \%$ & $5 \%$ & $95 \%$ & $0 \%$ \\
\hline \multicolumn{5}{|l|}{ Format } \\
\hline is attractive and interesting & $0 \%$ & $0 \%$ & $82 \%$ & $18 \%$ \\
\hline is clearly typed & $0 \%$ & $9 \%$ & $73 \%$ & $18 \%$ \\
\hline
\end{tabular}

Table 5 shows that the majority of the students agree that handout match the aims and the purpose of essay writing course $(A=82 \%+S A=14 \%)$ and only small number of students (4\%) think differently. In terms of the language and the format, the majority of the students also give positive feedback.

The next item in the questionaire for try out also investigate the students' opinion toward the content of the material. The students were asked whether the material had accomplished what it was intended to be, whether it was suitable with the students' need and level, whether it gave sufficient exercises, and whether it had its future usefulness. The result of the questionaire, in terms of content, shows that the majority of the students give positive responses toward the content.

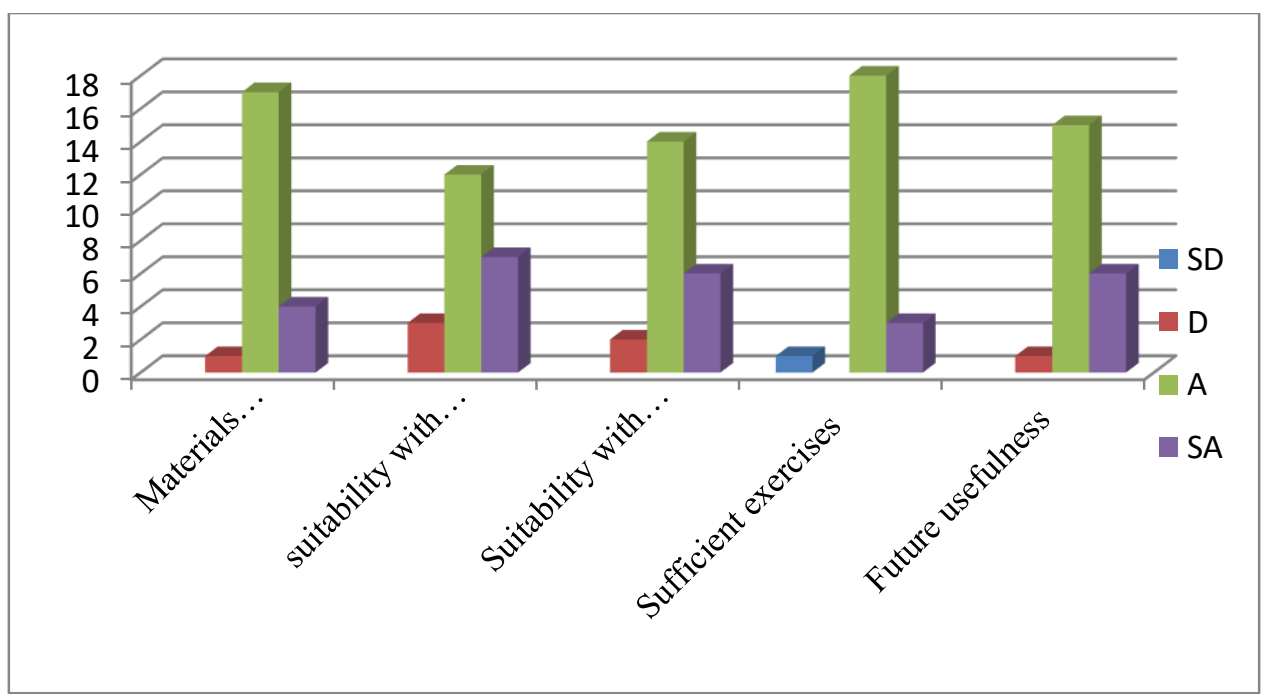

Figure 1. Content result of try out questionaire

In terms of content, the students felt that the materials had accomplished what they implied to $(77 \%)$. They also felt that it was suitable with the students' need (A+SA $=54 \%+32 \%)$, students' level $(A+S A=64 \%+27 \%)$, had sufficient exercises $(A+S A=$ $82 \%+14 \%)$, and was usefull for future language learning $(A+S A=68 \%+27 \%)$. 




Figure 2. Activities result of try out questionaire

The result of the questionaire in relation to the activities in the material handout also shows positive trends. Based on the students' opinion, the activities and tasks were presented in suitable sequence $(A+S A=73 \%+18 \%)$. They also felt that the activities in the handout were clear and consistent $(A+S A=91 \%+9 \%)$, interesting $(A+S A=68 \%+$ $9 \%)$, varied $(A+S A=77 \%+18 \%)$, appropriate with the topic being discussed $(A+S A=77 \%$ $+18 \%)$, and able to encourage their involvement $(A+S A=73 \%+27 \%)$.

To find out the effectiveness of the handout, the result of the students' writing was scored by two writing lecturers by using Jacobs ESL Composition Profile. The students' composition was rated based on five criteria, namely content, organization, vocabulary, language, and mechanic. The average score between the two raters was used to determine the effectiveness of the product by comparing it with the pre-test score. One sample test analysis was used to find out the difference between the mean.

Table 5. One-Sample Test

\begin{tabular}{lcccccc}
\hline & \multicolumn{2}{l}{ Test Value $=0$} & & & \\
& \cline { 3 - 7 } & $\mathrm{t}$ & $\mathrm{df}$ & $\begin{array}{c}\text { Sig. } \\
\text { (2-tailed) }\end{array}$ & $\begin{array}{c}\text { Mean } \\
\text { Difference }\end{array}$ & \multicolumn{2}{c}{$\begin{array}{c}\text { 95\% Confidence Interval of } \\
\text { the Difference }\end{array}$} \\
\cline { 6 - 8 } & & & & & Lower & Upper \\
\hline pretest & 60,265 & 31 &, 000 & 74,03125 & 71,5258 & 76,5367 \\
\hline posttest & 91,230 & 31 &, 000 & 80,53125 & 78,7309 & 82,3316 \\
\hline
\end{tabular}

The test analysis shows that there is a difference in the students' mean prior the use of the handout and after the use of the handout $(\alpha=0,00<0,005)$. This shows that the product is proven to be sufficiently effective to improve the students' writing performance.

\section{Revision of Final Product}

Based on the results of field testing, there were some items need further revision. They were the writing instructions, the sample essays, and the spelling. The writing instructions caused confusion for the students were revised. Based on the suggestions of the validators, the instructions were paraphrased and modified into simpler response toward the literary work as well as their critical thingking skills. In the revision, each chapter is given objectives of learning both for the rhetorical focus and the language focus. Second, the theory was made simpler and practical without too much wording. The sample essay given for the students in each unit came from the students' own writing to make it as authentic as possible. Third, the exercises were varied from group work to 
individual work. The group work exercises focused more on the analysis, grammar practice and pre-writing stage, while the individual work focuses on the creation of the essay. Next, the fictions used were selected on the basis of length, appropriateness and difficulty level. Most of the fictions used are the flash fictions type with less than 1,000 words. Fourth, some comprehensions questions were given after the reading passage in which some of the questions were the inferential questions type. And finally, the writing instructions responding to the topic were made as clear as possible relevant to the teaching goals.

\section{Discussion}

The use of literature for teaching language skills is not something new. It has been used long time ago for teaching a language (Gilmore, 2007). Literature as authentic materials offer many benefits for learners' communicative competence as it has rich sources for language learning (Takahashi, 2015). Within Indonesian context, literature has been used for teaching writing or integrated into other course in university level. For example, a study conducted by Setyowati \& Sukmawan (2018) who integrate the teaching of prose and essay writing. The result of the study shows that the integration of prose and essay, and vise versa, benefits the students' ability to write an essay as well as their critical thinking skills.

The finding of the study shows that the literature-based intructional material for essay writing class developed in this study work quite successful for teaching essay writing. The result of the students' questionaire responding to the material usage in the classroom shows that the majority of the students felt the use of the literature suits the goal of their learning. They also stated that the short stories match with the level of their language competence because they have no vocabulary problems and syntactical problems to understand the narrative. As they had no problems with the stories, they had little difficulty in terms of ideas and were able to express them on the paper.The insttructional material developed in this study used literature-based instruction in which most of the literary work used were in narative form, either prose or poem narrative. In the final revision of the product, the short stories used were those with less than 1,000 words length, which can be called as flash fiction. As all of them were taken for granted from the sources, i.e websites, without any simplifications and modifications, it can be said that the materials are authentic. As stated by Day (2004), appropriateness should be the main concern in selecteing the authentic materials. He further state that the appropriateness should cover the linguistic difficulty, variety of the target language, and activities and tasks given to the students.

The use of literature-based instruction for teaching writing skill should be integrated with reading skill. To begin with, previous studies shows that there is a strong and positive correlation between reading and writing performance (Choi, Moon, Paek, \& Kang, 2018; Motlaq \& Egresh, 2016; Palmer, 2010). These imply that the more the students read and write, the better their reading fluency and writing fluency will be. Research also shows that the conventional way of teaching of writing, focusing solely on writing practice and grammar instruction, has less effect on the students' writing performance than giving the students reading to write activities (Park, 2016). His research further shows that the students who were given extensive reading activities have more language input and have better writing performance both by using holistic scoring and analytical scoring, namely in content, organization, vocabulary, language and mechanic. Furthermore, as stated by Alomrani (2014) there should not be division between the teaching of reading and the teaching of writing, because the lack of readingwriting connection would not benefit learners. The use of literature-based instruction, where the students are exposed to literary work prior writing and then giving their personal opinion about it, is believed to give advantages for the students. This is in line 
as suggested by Alomrani (2014) that the integration of reading into writing activities should be placed in the planning and drafting phase in the process-oriented approach of writing.

To have better understanding of a reading text, or short story in this case, related to to the writing topic, the type of questions used for comprehension should not only focus on the explicit questions, but also the inferential questions. In this study, many of the questions used to understand the literary work are inferential questions instead of the literal ones. Research has shown that, inferential questions facilitate comprehension more (Ehara, 2008; Green, 2000). Inferential questions are a type of question that something about the text but the answer is not explicitly stated in the text. To get the answer from this type of question, the reader must work with the hints and clues in the passage combined with the personal knowledge and experience. The type of the inferential questions usually start with why and how although other type of wh-questions can also be used for the inferential questions, depending on the formulation of the questions. As inferential questions facilitate comprhension, the students would be able to give their opinion about the chosen literary work and relate their ideas with the writing topic in the form of the essay.

\section{Conclusion}

The result of the study shows that theinitial material was proven to be adequately successful to be used for essay wrting course. The present study implies that to develop a literature-based instruction materials for essay writing course, there are several things to consider. Firstly, the literature used in the handout should fulfil the criteria of appropriateness in terms of language difficulty and length. The language used in literary work, either prose or poems, should not be too difficult for the students and should not be too long, at least, less than 1,000 words work. The literature used in essay writing handout should be used only as a tool to provide the students' background knowledge. If the short stories or the poems are too difficult to comprehend, the classroom discussion would shift into literature class instead of writing class in which it should not be the case. Secondly, the goal of the teaching should focus on the writing activities instead of reading activities. It is true that there are some comprehension questions in the handout, but its presence are just to help the students to comprehend the stories and the time dedicated for reading activities should not be longer than the writing acitivities. And thirdly, the essay writing handout should be completed with the grammar activities related with the writing tasks the students are going to accomplish. It would be better if the grammar practices are in context related to the topic of the writing acitivity.

The instructional material developed in this study still needs to be perfected as it has some weaknesses. Firstly, selecting flash fiction matched with the writing goals, especially in the area of paragraph development, such as process, comparison and contrast, classification, problem solving, are quite challenging. More research need to be done to investigate the appropriateness and suitability of the fictions for writing class by using research and developnment design. Secondly, more research also needs to be done to find out the effectiveness of literary-based instruction as compared to other instructional material by using experimental design. And thirdly, more investigations need to be conducted to find out in what way the fictions used for writing essay benefits learners by using content analysis design. The information in relation to how the students write the opening paragraph, how they develop the body of the essay, and how to close the essay is necessary for improving the quality of both teaching and learning essay. All in all, the use of literature for teaching writing give benefits for the students, not only in terms of their writing skill and reading skill, but also in sharpening their critical thinking ability.

\section{Acknowledgements}


This research is fully supported by the Indonesian Directorate of Research and Community Engagement (DRPM DIKTI) of Higher Education for year funding in 2019

\section{References}

Alomrani, A. H. (2014). Integrating Reading Into Writing Instruction in the EFL Programs at Saudi Universities. Arab World English Journal, 5 (3), 100-112. Retrieved from www.awej.org

Block, C. C. (2005). Strategy Instruction in a Literature-Based Reading Program. The Elementary School Journal, 94(2), 139-151. https://doi.org/10.1086/461756

Choi, J., Moon, Y., Paek, J. K., \& Kang, Y. (2018). Examining the Relationship between Reading and Writing of Advanced Korean EFL Learners. Korean Journal of Applied Linguistics, 34(1), 91-116. https://doi.org/10.17154/kjal.2018.3.34.1.91

Day, R. R. (2004). A Critical Look at Authentic Materials. Spring, 1(1), 101-114.

Ehara, K. (2008). The Effects Of Types Of Question On EFL Learners' Reading Comprehension Scores. https://doi.org/10.1177/001088048102200214

Gall, M. D., Borg, W. R., \& Gall, J. P. (1996). Educational research: An introduction, 6th ed. In Educational research: An introduction, 6th ed.

Gibson, J. (2007). Fiction and the Weave of Life. In Fiction and the Weave of Life. https://doi.org/10.1093/acprof:oso/9780199299522.001.0001

Gilmore, A. (2007). Authentic materials and authenticity in foreign language learning. Language Teaching. https://doi.org/10.1017/s0261444807004144

Green, L. B. (2000). Fourth graders' literal and inferential reading comprehension: Effects of readability and answer format. Retrieved from https://search.proquest.com/docview/304637813?accountid=14548\%0Ahttps://jul ac.hosted.exlibrisgroup.com/openurl/HKU_ALMA/SERVICES_PAGE??url_ver=Z 39.88-

2004\&rft_val_fmt=info:ofi/fmt:kev:mtx:dissertation\&genre=dissertations+\%26+the ses\&sid=ProQ:ProQuest+Dissert

Hismanoglu, M. (2005). Teaching English Through Literature. Journal of Language and Linguistic Studies. https://doi.org/10.17263/jlls.38648

Janssen, G., Meier, V., \& Trace, J. (2015). Building a Better Rubric: Mixed methods rubric revision. Assessing Writing. https://doi.org/10.1016/j.asw.2015.07.002

Khatib, M., Rezaei, S., \& Derakhshan, A. (2011). Literature in EFL/ESL Classroom. English Language Teaching, 4(1), 201. https://doi.org/10.5539/elt.v4n1p201

Lazar, G. (2010). Literature and Language Teaching. In Literature and Language Teaching. https://doi.org/10.1017/cbo9780511733048

Lehman, B. A., Freeman, E. B., \& Allen, V. G. (1994). Children's Literature And Literacy Instruction: "Literature-Based" Elementary Teachers' Belief And Practices. Reading Horizons, 35(1), 3-29. Retrieved from https://georgefox.idm.oclc.org/login?url=http://search.ebscohost.com/login.aspx? direct=true $\& \mathrm{db}=$ eft $\& A \mathrm{~N}=508504372 \&$ scope $=$ site

Motlaq, H. S., \& Egresh, N. (2016). The Relationship between Reading Ability and Writing Quality among Iranian EFL Academic Writers. International Journal Of Humanities 
And Cultural Studies ISSN, 3(2), 2356-5926. Retrieved from http://www.ijhcs.com/index.php/ijhcs/index

Palmer, M. L. (2010). The Relationship Between Reading Fluency, Writing Fluency, and Reading Comprehension In Suburban Third-Grade Students. Retrieved from http://libproxy.lib.unc.edu/login?url=http://search.proquest.com/docview/8174041 70 ?accountid=14244\%5Cnhttp://vb3lk7eb4t.search.serialssolution.com?ctx_ver= Z39.88-2004\&ctx_enc=info:ofi/enc:UTF-

8\&rfr_id=info:sid/ProQuest+Dissertations+\%26+Theses+Global\&rft_val

Park, J. (2016). Integrating reading and writing through extensive reading. ELT Journal, 70(3), 287-295. https://doi.org/10.1093/elt/ccv049

Setyowati, L. (2016). Analyzing The Students'ability In Writing Opinion Essay Using Flash Fiction. Journal of English Language Teaching and Linguistics, 1(1), 79. https://doi.org/10.21462/jeltl.v1i1.1

Setyowati, L.-. (2017). Gender Ideals Violation in Domestic and Economic Life as Found in Margaret Mitchell's Gone With The Wind. Humaniora, 8(2), 165. https://doi.org/10.21512/humaniora.v8i2.2562

Setyowati, L., \& Sukmawan, S. (2018). Writing for Comprehension in Prose Fiction Analysis: The Students' Voices. Arab World English Journal, 9(1), 134-145. https://doi.org/10.24093/awej/vol9no1.10

Takahashi, K. (2015). Literary Texts as Authentic Materials for Language Learning: The Current Situation in Japan. In Literature and Language Learning in the EFL Classroom (pp. 26-40). https://doi.org/10.1057/9781137443663 